\title{
COMMENTARY
}

\section{Championing of dementia in England}

\author{
Zeinab Abdi and Alistair Burns ${ }^{2, *}$
}

\begin{abstract}
Dementia is starting to attract attention following decades of comparative neglect relative to other disease areas. England has been at the forefront of this sea change as one of the first countries in the world to develop a National Dementia Strategy (in 2009). Events leading up to the publication of this strategy and since will be examined here together with a glimpse at the international landscape.
\end{abstract}

\section{Introduction}

An estimated 800,000 people live with dementia in the UK, at a cost of $£ 23$ billion annually [1]. By 2021 the number of people with dementia is expected to rise to over 1 million with an associated increase in costs. There has been somewhat of an attitude shift towards dementia of late - after decades of relative obscurity relative to diseases such as cancer and cardiovascular disease, dementia is now firmly on the national health and social care policy agenda of many high income countries.

\section{Dementia policy in England}

Living Well with Dementia, A National Dementia Strategy (NDS) for England was published in 2009 [2], setting out a vision for the transformation of dementia services following reports by the National Audit Office [3] and the Public Accounts Committee [4] concluding that dementia services provided poor value for money and that national policy had not prioritised dementia sufficiently. The same year saw the publication of the Banerjee report [5], 'Time for Action'. The report highlighted the problem use of antipsychotics in those with dementia and led to the reduced use of antipsychotic medication being included in the top five priorities in the updated implementation plan for the NDS as well as good quality early diagnosis and intervention for all,

*Correspondence: Alistair.burns@dh.gsi.gov.uk

2Department of Health, Wellington House, 135-155 Waterloo Road London,

SE1 8UG, UK

Full list of author information is available at the end of the article improved quality of care in hospitals, living well with dementia in care homes and support for carers. As part of the focus on antipsychotics, 'The Right Prescription: a call to action on the use of antipsychotics', a joint initiative between the Dementia Action Alliance and the National Health Service (NHS) Institute for Innovation and Improvement to tackle the problem of antipsychotic prescribing in dementia, was launched in 2011 and is ongoing [6]. This initiative will ensure that every person with dementia on an antipsychotic will have a clinical review of their treatment. In July 2012 the results of a national audit showed a $50 \%$ reduction in the prescribing of antipsychotics in dementia in England between 2008 and 2011, which is encouraging, although regional variations do remain [7].

In March 2012 the UK Prime Minister (PM), David Cameron, launched the latest drive to improve the care of those with dementia by 2015, announcing three key commitments: improvements in health and care, creation of dementia friendly communities and better research [8]. The PM challenge will build on the progress of the NDS but aims to 'push further and faster to improve the quality of life for people living with dementia, their families and carers. Among the plans was a more than doubling of the funding for research to over $£ 66$ million by 2015 . The implementation plan for the PM challenge is now under way with working groups established to oversee each strand of the challenge with regular progress feedback to the PM's office.

Several reports have highlighted the poor care of patients with dementia in hospitals, the latest of which, the National Dementia Audit run by the Royal College of Psychiatrists in 2011, asked for significant improvements to be made to the care of inpatients with dementia [9]. 2012 also saw the launch of the dementia Commissioning for Quality and Innovation (CQUIN) payment framework, which rewards the identification of cognitive impairment in hospital inpatients aged 75 years and over [10]. This framework aims to drive up diagnosis rates of dementia, currently standing at $42 \%$, improve inpatient services for those admitted with dementia by ensuring the diagnosis is recorded and to identify potentially reversible causes of cognitive impairment in the elderly, such as delirium and depression. The need to improve diagnosis rates and reduce regional variation has also 
been highlighted by an All-Party Parliamentary Group report on dementia in July 2012 [11].

Dementia is a high level priority in the 2012/13 NHS operating framework, the document setting out the national priorities and strategy for the NHS [12]. Dementia also currently has a placeholder on the 2012/13 NHS outcomes framework, a set of indicators that will be used to hold the Clinical Commissioning Groups accountable to the NHS commissioning Board on outcomes [13].

\section{International picture}

Internationally, dementia is being championed across the world and several countries now have national dementia plans that can be accessed on the Alzheimer Europe [14] and Alzheimer's Disease International (ADI) [15] websites. Common themes in the strategies include early diagnosis, awareness raising, quality care, staff training, and research into prevention and better management of the disorder pharmacologically, behaviourally and socially. 2012 saw the launch of the first US national Alzheimer plan, with a number of goals, including the ambition to 'prevent and effectively treat Alzheimer's disease by 2025’ [16].

In April 2012 a joint report was launched by the World Health Organisation (WHO) and ADI - 'Dementia: a Public Health Priority' - calling for raised awareness and governmental action globally [17]. It reported that, currently, $58 \%$ of all those with dementia live in low and middle income countries where the majority of dementia care is currently provided by extended families, with this figure projected to rise to $71 \%$ by 2050 given current population trends. The WHO advice to low and middle income countries, whose efforts have tended to centre on the prevention of communicable diseases, with a lack of specific dementia plans to date, is to focus on capacity building, including infrastructure and workforce training across the health and social care sector to enable a response to the dementia challenge. The report suggests dementia can be incorporated into older people or mental health national policies for these countries.

\section{Partnership working}

Non-governmental organisations such as the Alzheimer's Society (UK) [18], Alzheimer's Association (USA) [19] and ADI play a central role in shaping and supporting national and international policy, including national plans. In the UK, for example, the Alzheimer's Society has been integral to the development and implementation phase of the 2009 national plan [2] and is overseeing the dementia friendly communities strand of the recent PM dementia challenge [8]. Equally, France Alzheimer is a major partner in the French national plan [20].

Furthermore, collaboration between public bodies and the commercial sector through data sharing and the setting of common research priorities is increasingly being recognised as a means of maximising opportunities, such as the identification of drug targets and novel biomarkers allowing for early intervention and prevention. The ministerial advisory group on dementia research in the UK has highlighted the need for crosssector working in dementia, which will be addressed as part of a joint initiative between the Medical Research Council and the Association of the British Pharmaceutical Industry looking at a partnership working across a number of disease areas [21]. Most recently, David Cameron spoke about plans developed as part of the 'Strategy for UK Life Sciences' [22] to share anonymised NHS patient data with universities and industry for the promotion of life sciences innovation, including in the field of dementia [23].

\section{Conclusion}

There is a real sense that dementia's time is here in terms of priorities and is finally being recognised as a matter of national priority with commitment from governments across the world. It is now imperative that this momentum is seized upon to deliver on strategies to improve the lives of people with dementia and their carers.

\section{Abbreviations}

ADI, Alzheimer's Disease International; NDS, National Dementia Strategy; NHS, National Health Service; PM, Prime Minister; WHO, World Health Organisation.

\section{Competing interests}

This article was commissioned whilst Zeinab Abdi worked as a secondee to the Department of Health's older people and policy team, January to March 2012 and has been written in a personal capacity. Alistair Burns is the National Clinical Director for dementia for England, based at the Department of Health.

\section{Author details}

'Royal College of Physicians, 11 St Andrews Place, Regent's Park, London, NW1 4LE, UK. ² Department of Health, Wellington House, 135-155 Waterloo Road London, SE1 8UG, UK.

Published: 11 September 2012

\section{References}

1. Alzheimer's Society Dementia 2012 Report [http://alzheimers.org.uk/site/ scripts/download info.php?filelD=1389]

2. Department of Health: Living well with dementia: a National Dementia Strategy [http://www.dh.gov.uk/prod_consum_dh/groups/dh_ digitalassets/@dh/@en/documents/digitalasset/dh_094051.pdf]

3. National Audit Office: Improving services and support for people with dementia [http://www.nao.org.uk/publications/0607/dementia_services_ and_support.aspx]

4. Committee of Public Accounts: Improving Services and Support for People with Dementia: Sixth report of session 2007-8 [http://www.publications. parliament.uk/pa/cm200708/cmselect/cmpubacc/228/228.pdf]

5. Sube Banerjee: The use of antipsychotic medication for people with dementia: time for action [http://www.dh.gov.uk/prod consum dh/ groups/dh_digitalassets/documents/digitalasset/dh_108302.pdf]

6. NHS Institute for Innovation and Improvement: The Right Prescription: a call to action on the use of antipsychotic drugs for people with dementia [http://www.institute.nhs.uk/qipp/calls_to_action/Dementia_and_ antipsychotic_drugs.html/]

7. Health and Social Care Information Centre: National Dementia and Antipsychotic Prescribing Audit 2012 [http://www.ic.nhs.uk/webfiles/ 
Services/NCASP/audits\%20and\%20reports/National_Dementia_and_ Antipsychotic_Prescribing_Audit_National_Report_V1.0_17_07_12_ Interactive.pdf]

8. Department of Health: Prime Minister's challenge on dementia. Delivering major improvements in dementia care and research by 2015 [http://www. dh.gov.uk/prod_consum_dh/groups/dh_digitalassets/@dh/@en/ documents/digitalasset/dh_133176.pdf]

9. Royal College of Psychiatrists: Report of the National Audit of Dementia Care in General Hospitals 2011 [http://www.rcpsych.ac.uk/pdf/ NATIONAL\%20REPORT\%20-\%20Full\%20Report\%201201122.pdf]

10. Department of Health: Using the Commissioning for Quality and Innovation (CQUIN) payment framework: Guidance on new national goals for 2012-13 [http://www.dh.gov.uk/prod_consum_dh/groups/dh_ digitalassets/@dh/@en/documents/digitalasset/dh_133859.pdf]

11. Alzheimer's Society: Unlocking Diagnosis: All-Party Parliamentary Group Report 2012 [http://alzheimers.org.uk/site/scripts/download_info. php?filelD=1457]

12. Department of Health: The Operating Framework for the NHS in England 2012/13 [http://www.dh.gov.uk/prod_consum_dh/groups/dh_digitalassets/ documents/digitalasset/dh_131428.pdf]

13. Department of Health: The NHS Outcomes Framework 2013/13 [http:// www.dh.gov.uk/prod_consum_dh/groups/dh_digitalassets/documents/ digitalasset/dh_131723.pdf]

14. Alzheimer Europe: National Dementia Plans [http://www.alzheimer-europe. org/EN/Policy-in-Practice2/National-Dementia-Plans]
15. Alzheimer's Disease International: Government Alzheimer plans [http://www.alz.co.uk/alzheimer-plans]

16. US Department of Health and Social Services: National Plan to Address Alzheimer's Disease [http://aspe.hhs.gov/daltcp/napa/NatlPlan.pdf]

17. World Health Organisation: Dementia, a Public Health Priority [http://whqlibdoc.who.int/publications/2012/9789241564458_eng.pdf]

18. Alzheimer's Society [http://alzheimers.org.uk/]

19. Alzheimer's Association [http://www.alz.org/]

20. Alzheimer Europe: France - National Plans for Alzheimer and related diseases [http://www.alzheimer-europe.org/Policy-in-Practice2/NationalDementia-Plans/France\#fragment-1]

21. Department of Health: The Ministerial Advisory Group on Dementia Research: Headline Report [http://www.dh.gov.uk/prod_consum_dh/ groups/dh_digitalassets/documents/digitalasset/dh_127904.pdf]

22. Department for Business, Skills and Innovation: Strategy for UK Life Sciences [http://www.bis.gov.uk/assets/biscore/innovation/ docs/s/11-1429-strategy-for-uk-life-sciences]

23. PM Speech at Global Health Policy Summit [http://www.number10.gov.uk/ news/global-health-policy/]

doi:10.1186/alzrt139

Cite this article as: Abdi Z, Burns A: Championing of dementia in England. Alzheimer's Research \& Therapy 2012, 4:36. 